\title{
Using the Turkish Red Pine Tree to Monitor Heavy Metal Pollution
}

\author{
Ibrahim Ertugrul Yalcin ${ }^{1}$, Ibrahim Ilker Ozyigit ${ }^{2,3 *}$, Ilhan Dogan ${ }^{4 * *}$, \\ Goksel Demir ${ }^{5}$, Celal Yarci²
}

${ }^{1}$ Bahcesehir University, Faculty of Engineering and Natural Sciences, Department of Civil Engineering, Besiktas, Istanbul, Turkey

${ }^{2}$ Marmara University, Faculty of Science and Arts, Department of Biology, Goztepe, Istanbul, Turkey

${ }^{3}$ Kyrgyz-Turkish Manas University, Faculty of Science, Department of Biology, Bishkek, Kyrgyzstan ${ }^{4}$ Izmir Institute of Technology, Faculty of Science, Department of Molecular Biology and Genetics, Urla, Izmir, Turkey

${ }^{5}$ Health Sciences University, Faculty of Hamidiye Health Sciences, Department of Occupational Health and Safety, Uskudar, Istanbul, Turkey

Received: 10 September 2019

Accepted: 21 November 2019

\begin{abstract}
Turkish red pine is an evergreen tree species widely distributed in the Aegean and Mediterranean regions in Turkey. In the present work, the heavy metal pollution level in Istanbul was investigated using Turkish red pine as a biomonitor. For determining heavy metal concentrations ( $\mathrm{Cd}, \mathrm{Co}, \mathrm{Cr}, \mathrm{Mn}, \mathrm{Ni}$ and $\mathrm{Pb}$ ) in leaf (unwashed and washed) and bark samples of Turkish red pine and its co-located soil samples we used ICP-OES. Additionally, particulate matter profiles of the research areas were investigated. The samples were collected from 5 different localities: 4 from the Bosporus region (Yildiz Grove, Fethi Pasha Grove, Baltalimani Grove and Mihrabad Grove) and one from Prince Island, also known as Buyukada (as control). According to our measurements, the highest heavy metal accumulations (in mg kg-1 DW) in plant part samples were measured between $1.526 \pm 0.012$ and $1.639 \pm 0.015$ for $\mathrm{Cd}$, $0.543 \pm 0.007$ and $0.600 \pm 0.009$ for $\mathrm{Co}, 5.110 \pm 0.064$ and $5.648 \pm 0.072$ for $\mathrm{Cr}, 9.347 \pm 0.105$ and $10.331 \pm 0.111$ for $\mathrm{Mn}, 7.483 \pm 0.091$ and $8.271 \pm 0.096$ for $\mathrm{Ni}$, and $13.848 \pm 0.159$ and $14.950 \pm 0.167 \mathrm{for} \mathrm{Pb}$, while the highest heavy metal accumulations (in $\mathrm{mg} \mathrm{kg}^{-1} \mathrm{DW}$ ) in soil samples were measured between $1.813 \pm 0.021$ and $1.974 \pm 0.029$ for $\mathrm{Cd}, 6.326 \pm 0.082$ and $6.992 \pm 0.091$ for Co, 22.017 \pm 0.284 and $23.685 \pm 0.301$ for $\mathrm{Cr}$, $268.333 \pm 3.153$ and $297.361 \pm 3.529$ for $\mathrm{Mn}, 15.194 \pm 0.176$ and $16.792 \pm 0.193$ for $\mathrm{Ni}$, and $68.778 \pm 0.715$ and $74.514 \pm 0.883$ for $\mathrm{Pb}$. The highest outdoor particulate matter levels (in $\left.\mu \mathrm{g} / \mathrm{m}^{3}\right)$ in research areas were also determined as 27.103 for fine $\left(\mathrm{PM}_{2.5}\right)$ and 67.792 for coarse $\left(\mathrm{PM}_{10}\right)$ aerosols. The findings revealed that Turkish red pine could accumulate noteworthy amounts of heavy metals.
\end{abstract}

Keywords: heavy metals, particulate matter (PM), Pinus brutia, contamination

*e-mail: ilker.ozyigit@manas.edu.kg

**e-mail: ilhandogan@iyte.edu.tr 


\section{Introduction}

The levels of heavy metal pollution in the biosphere have substantially increased since the 1900s [1]. The long-term release of heavy metals into the atmosphere has resulted in environmental pollution at everincreasing rates. As a result, environmental pollution has been a major reason for human health problems globally $[2,3]$. The number of studies on heavy metal pollution has extensively increased in the last few decades, which has raised environmental awareness and spurred necessary protective actions [4-6].

Metals with a density greater than $5 \mathrm{~g} / \mathrm{cm}^{3}$ are defined as heavy metals [7]. Some heavy metals such as $\mathrm{As}, \mathrm{Cd}, \mathrm{Cr}, \mathrm{Hg}$ and $\mathrm{Pb}$ are naturally available, but they are not required for living organisms since even their minute amounts could be detrimental $[8,9]$. Heavy metal-related environmental pollution, particularly following industrial revolution, have caused grave ecological problems [10]. Once incorporated into biological systems, heavy metals are accumulated to a certain point, and excess levels lead to the toxicity resulting in various symptoms or even loss of viability $[11,12]$. Therefore, it is necessary to take measurements on a regular basis for determining the level of environmental pollution, especially for people living in crowded cities. Especially in underdeveloped or developing countries, the application of advanced technologies and implementation of necessary measurements on pollution prevention has been poor due to insufficient environmental regulations, and unplanned and uncontrolled urbanization [13].

The data from WHO attributes to indoor air pollution shows a globally significant number of deaths (more than 1.5 million) and a high percentage of disease existence $(2.7 \%$ of total). Indoor air pollution as a major risk factor responsible for $3.7 \%$ of global disease in developing countries comes after malnutrition, the HIV/AIDS epidemic and lack of safe water and adequate sanitation. Smoke during cooking activities makes women and children most vulnerable to indoor hazardous pollutants [14].

Today, not only soil, water and air measurements, but also biomonitor species or parts of these biomonitor species are commonly used for the assessment of environmental pollution $[15,16]$. However, a biomonitor is an organism that provides quantitative information about environmental quality [17-19]. In pollution studies, plant (root, leaf and bark etc.), animal (liver, heart and lung etc.) and human (skin, hair, blood, milk, urine, mucus, nail, and saliva, etc.) parts could be utilized as bioindicators [20]. In contrast, in recent years various parts of higher plants, lichens, mosses, algae, yeast, and fungal species have been extensively used in biomonitoring activities [21-23]. Particularly evergreen higher plants, rather than annuals, are preferred in biomonitoring studies since they could provide more relevant information on short/long-term toxicity levels $[24,25]$.
Some studies on Turkish red pine, an evergreen tree from the Pinaceae family widely distributed throughout the Mediterranean and Aegean regions of Turkey, revealed its biomonitoring ability [26-28]. Because of its long-term accumulation capability for heavy metals, Turkish red pine was used as a biomonitor organism in order to investigate pollution levels in Istanbul. In this regard, estimating $\mathrm{Cd}, \mathrm{Co}, \mathrm{Cr}, \mathrm{Mn}, \mathrm{Ni}$ and $\mathrm{Pb}$ concentrations was done using leaf (unwashed and washed) and bark samples of Turkish red pine and its co-located soil samples collected from five different locations. In addition, for short-term estimation, the levels of $\mathrm{PM}_{10}$ and $\mathrm{PM}_{2.5}$ in research areas were also determined.

\section{Materials and Methods}

\section{Study Area}

Our study area, Istanbul, is located in northwestern Turkey and covers a total of $5343 \mathrm{~km}^{2}$. The city extends both on the Asian (Anatolia) and European (Thrace) sides of the Bosphorus in the Marmara Region [29]. At the end of 2019, it is population reached more than 15 million - making it the most populous city in Turkey with $18.6 \%$ of the population [30]. As a financial and cultural center, this megacity has 39 districts administered by Istanbul Municipality. About 20\% of industrial labor of Turkey is employed in Istanbul; thus, it contributes $38 \%$ of Turkey's industrial workspace [31].

Plant and soil samplings were performed at five different locations: Buyukada (as control), Yildiz Grove, Fethi Pasha Grove, Baltalimani Grove and Mihrabad Grove (Fig. 1). Buyukada covers an area of $5.4 \mathrm{~km}^{2}$ and Maltepe shore is the nearest terrestrial location to the island at a distance of $2300 \mathrm{~m}$. The island is less populated in comparison with other research areas. It has almost no motor vehicle traffic, especially in winter [31]. Yildiz Grove is located in Besiktas, a historic district of Istanbul, covering an area of about $500000 \mathrm{~m}^{2}$ [31]. Fethi Pasha grove, situated in Uskudar District between Kuzguncuk and Sultantepe neighborhoods on the Asian side, covers 16 hectares of green area. Baltalimani Grove, located on the European side of Istanbul, extends from Hisar Kemal Street to Kemal Caglar Street, covering the hills between these streets. Mihrabad Grove, situated in Kanlica District on the Asian side on a vast area of 200 acres, harbors many plant and tree species [32].

\section{Sample Collection, Preparation and Analysis}

Samples were collected from the above-mentioned locations. Leaf samples were divided into two groups: for performing analysis, one half was rinsed with de-ionized distilled water for removing dust particles on leaves and the other half was used without using de-ionized distilled water. The isolated plant parts 


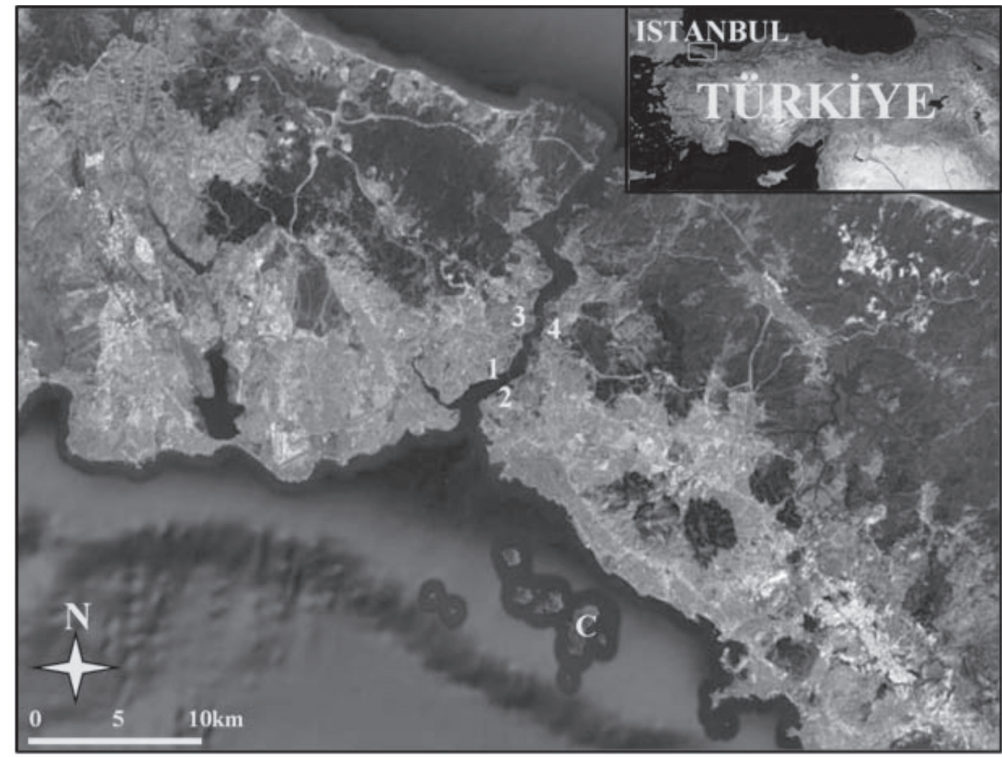

Fig. 1. Satellite map showing Istanbul Province of Turkey (modified from Google Earth); sampling sites are indicated in yellow: C for Buyukada (as control), 1 for Yildiz Grove, 2 for Fethi Pasha Grove, 3 for Baltalimani Grove, and 4 for Mihrabad Grove.

(barks and leaves) were dried in an oven at $80^{\circ} \mathrm{C}$ for $24 \mathrm{~h}$. After that, weighted $0.2 \mathrm{~g}$ of each plant part sample was transferred into Teflon vessels and then $8 \mathrm{ml} 65 \% \mathrm{HNO}_{3}$ (Merck) was added to each sample. Soil samples $(\sim 500 \mathrm{~g}$ each) taken from a depth of about $10 \mathrm{~cm}$ using a shovel were dried by air and sieved using a $2 \mathrm{~mm}$ sifter. Then, $6 \mathrm{ml} \mathrm{HNO}_{3}(65 \%), 3 \mathrm{ml}$ $\mathrm{HCl}(37 \%)$ and $2 \mathrm{ml} \mathrm{HF}$ (48\%) (Merck) were added to $0.250 \mathrm{~g}$ of each soil sample. Sample mineralization was done using a microwave oven (Berghof-MWS2) at $145^{\circ} \mathrm{C}$ for $5 \mathrm{~min}, 165^{\circ} \mathrm{C}$ for $5 \mathrm{~min}$, and $175^{\circ} \mathrm{C}$ for $20 \mathrm{~min}$. After cooling, the samples were passed through a 1-2 $\mu \mathrm{m}$ filter paper and filled up to $50 \mathrm{ml}$ volume with ultrapure water in falcon tubes [8]. Using multi-element stock solutions, $1000 \mathrm{ppm}$ (Merck), standard solutions were prepared. The concentrations of $\mathrm{Cd}, \mathrm{Co}, \mathrm{Cr}, \mathrm{Mn}$, $\mathrm{Ni}$ and $\mathrm{Pb}$ were determined using inductively coupled plasma optical emission spectroscopy (PerkinElmerOptima 7000 DV). An aerosol monitor (TSI DustTrak II-8530) was also employed for measuring the mass fraction concentrations of $\mathrm{PM}_{10}$ and $\mathrm{PM}_{25}$ [33]. The field measurements were done for three days during sampling periods.

\section{Statistical Analysis}

Statistical analysis and other calculations were performed using the data from heavy metal concentration measurements on a dry weight (DW) basis. Multivariate analysis of variance (MANOVA) with Tukey's post-hoc HSD, Pearson correlation and hierarchical cluster analysis were done using IBM SPSS Statistics 20 software. The levels of statistical significance were expressed as $0.01\left(^{* *}\right)$ and $0.05\left(^{*}\right)$ levels (2-tailed). Tukey's post-hoc test was applied for localities.

\section{Results and Discussion}

The concentrations of $\mathrm{Cd}, \mathrm{Co}, \mathrm{Cr}, \mathrm{Mn}, \mathrm{Ni}$ and $\mathrm{Pb}$ in barks and leaves of Turkish red pine and its co-located soil samples from five different Istanbul locations were determined using ICP-OES. In addition, the terms "washed" and "unwashed" will be abbreviated hereafter as "w" and "uw."

The average concentrations of heavy metals $(\mathrm{Cd}$, $\mathrm{Co}, \mathrm{Cr}, \mathrm{Mn}, \mathrm{Ni}$ and $\mathrm{Pb}$ ) in plant parts and soil samples showed the highest values at station 1 , whereas the lowest were found at the control station. In the plant samples the highest values and lowest values (in $\mathrm{mg} \mathrm{kg}$ ) were recorded as: $1.526 \pm 0.012-1.639 \pm 0.015$ (in bark) and $0.297 \pm 0.003-0.316 \pm 0.005$ (in w leaf) for $\mathrm{Cd}$; $0.543 \pm 0.007-0.600 \pm 0.009$ (in uw leaf) and $0.060 \pm 0.001-0.067 \pm 0.001$ (in bark) for Co; $5.110 \pm 0.064$ $5.648 \pm 0.072$ (in uw leaf) and $0.819 \pm 0.011-0.907 \pm 0.013$ (in bark) for $\mathrm{Cr}$; 9.347 $\pm 0.105-10.331 \pm 0.111$ (in uw leaf) and 3.543 $\pm 0.051-3.921 \pm 0.055$ (in w leaf) for $\mathrm{Mn}$; $7.483 \pm 0.091-8.271 \pm 0.096$ (in uw leaf) and $0.829 \pm 0.010$ $0.949 \pm 0.013$ (in w leaf) for $\mathrm{Ni}$; and $13.848 \pm 0.159$ $14.950 \pm 0.167$ (in bark) and 3.718 $\pm 0.048-4.285 \pm 0.057$ (in w leaf) for $\mathrm{Pb}$, respectively (Fig. 2), while in the soil samples the highest values and lowest values (in $\mathrm{mg} \mathrm{kg}-1)$ were recorded as: $1.813 \pm 0.021-1.974 \pm 0.029$ and $0.744 \pm 0.009-0.844 \pm 0.011$ for $\mathrm{Cd} ; 6.326 \pm 0.082$ $6.992 \pm 0.091$ and $3.358 \pm 0.044-4.328 \pm 0.052$ for Co; $\quad 22.017 \pm 0.284-23.685 \pm 0.301$ and $11.931 \pm 0.159$ $13.194 \pm 0.181$ for $\mathrm{Cr} ; 268.333 \pm 3.153-297.361 \pm 3.529$ and $140.694 \pm 2.046-145.556 \pm 2.225$ for $\mathrm{Mn}$; $15.194 \pm 0.176-$ $16.792 \pm 0.193$ and $7.042 \pm 0.092-7.782 \pm 0.102$ for $\mathrm{Ni}$; and $\quad 68.778 \pm 0.715-74.514 \pm 0.883$ and $29.991 \pm 0.305$ $32.479 \pm 0.411$ for $\mathrm{Pb}$, respectively (Fig. 3).

The normal worldwide distributions of the studied heavy metals in $\mathrm{mg} \mathrm{kg}^{-1}$ in soils are in ranges of: 
0.06-1.1 with 0.5 global average for $\mathrm{Cd}$; 4.5-12 with 10 global average for Co (in surface soils); and 54 (global average) for $\mathrm{Cr}$ [34]. Generally, the $\mathrm{Mn}$ contents (in $\mathrm{mg} \mathrm{kg}^{-1}$ ) in soil lie between 270 (podzols) and 525 (cambisols), but overall the worldwide average is found to be 437 [35]. However, the Mn contents (in $\mathrm{mg} \mathrm{kg}^{-1}$ ) in soils are highly diverse worldwide and range from 10 to 9000 . Ni is one of the micronutrients and also a heavy metal, and it occurs in soils (in $\mathrm{mg} \mathrm{kg}$ ) in the range of $0.2-450$ with the average between 19-22. The natural $\mathrm{Pb}$ concentrations (in $\mathrm{mg} \mathrm{kg}^{-1}$ ) originated from the main rocks in regions between 10 and 40, with a grand average of 25 [34].
$\mathrm{Cd}(\mathrm{mg} / \mathrm{kg})$

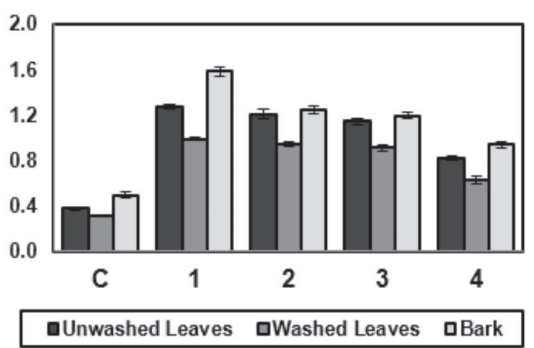

Co $(\mathrm{mg} / \mathrm{kg})$

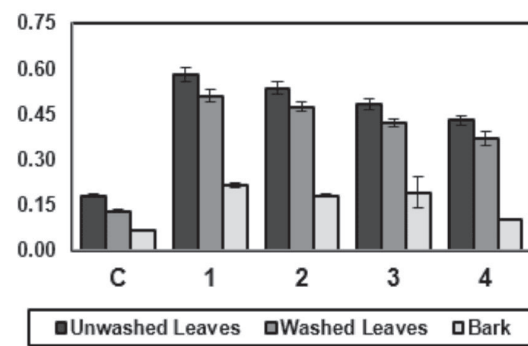

$\mathrm{Cr}(\mathrm{mg} / \mathrm{kg})$

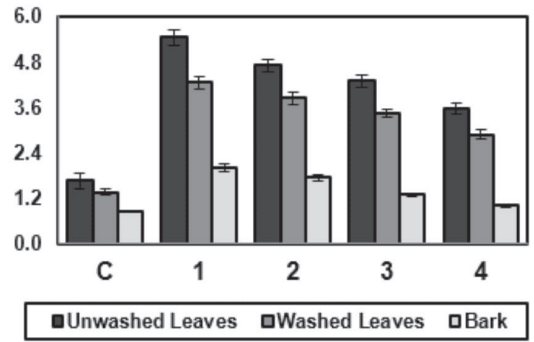

$\mathrm{Mn}(\mathrm{mg} / \mathrm{kg})$

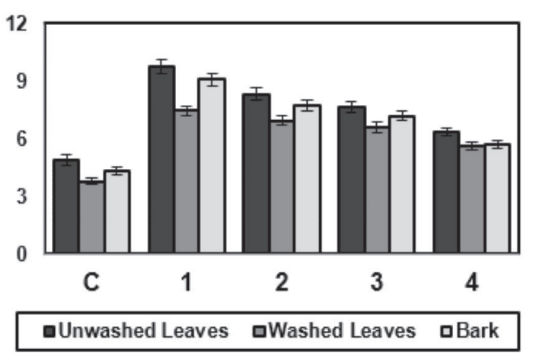

$\mathrm{Ni}(\mathrm{mg} / \mathrm{kg})$

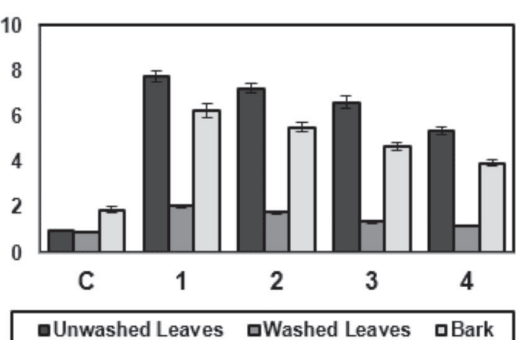

$\mathrm{Pb}(\mathrm{mg} / \mathrm{kg})$

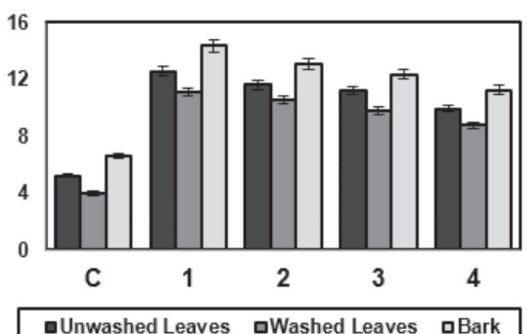

Fig. 2. Estimated concentrations of $\mathrm{Cd}, \mathrm{Co}, \mathrm{Cr}, \mathrm{Mn}, \mathrm{Ni}$ and $\mathrm{Pb}$ in leaf (washed and unwashed) and bark samples of Turkish red pine; estimations are given as $\mathrm{mg} \mathrm{kg}^{-1} \mathrm{DW}$ and sampling sites are indicated as: C for Buyukada (as control), 1 for Yildiz Grove, 2 for Fethi Pasha Grove, 3 for Baltalimani Grove, and 4 for Mihrabad Grove.
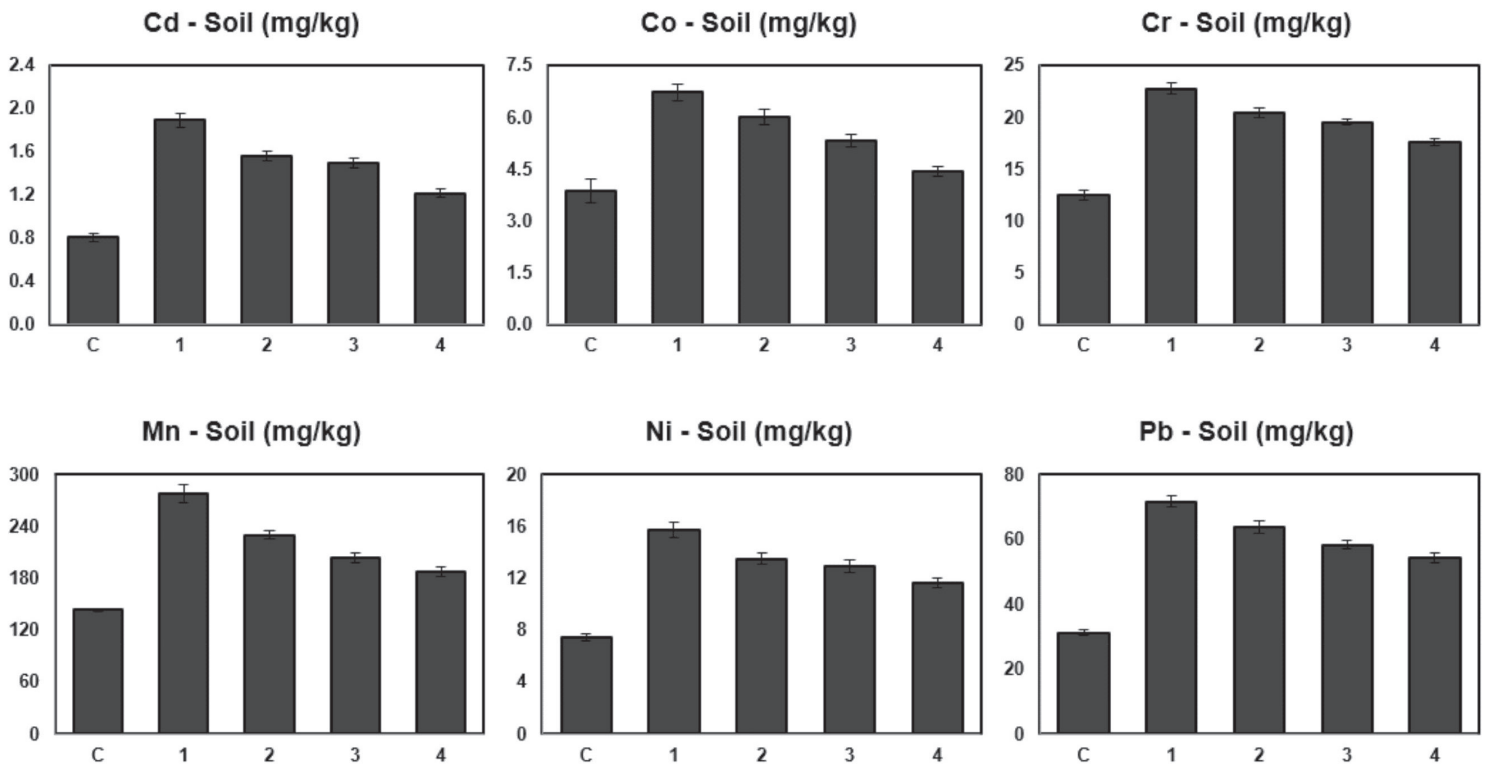

Fig. 3. Estimated concentrations of $\mathrm{Cd}, \mathrm{Co}, \mathrm{Cr}, \mathrm{Mn}, \mathrm{Ni}$ and $\mathrm{Pb}$ in soil samples in localities; estimations are given as $\mathrm{mg} \mathrm{kg}^{-1} \mathrm{DW}$ and sampling sites are: C for Buyukada (as control), 1 for Yildiz Grove, 2 for Fethi Pasha Grove, 3 for Baltalimani Grove, and 4 for Mihrabad Grove. 
The normal worldwide distributions of the studied heavy metals (in $\mathrm{mg} \mathrm{kg}^{-1}$ ) in the plant bodies are in ranges of: $0.05-0.5$ for $\mathrm{Cd}$ [36]; $0.005-0.270$ in cereal grains, $0.100-0.570$ in clovers and $0.060-0.270$ in grasses for Co (therefore, the contents of Co in plants could be in the range of $0.005-0.570$ ) [34]; 0.006-18 in plants for $\mathrm{Cr}$ [37]; 30-300 in plant parts for $\mathrm{Mn}[35,38]$; 0.5-5 in plant tissues for $\mathrm{Ni}$; and $5-10$ and above 30 is considered as toxic in plants for $\mathrm{Pb}[35,38]$, respectively.

When the results obtained in our study are compared with the abovementioned values, the concentrations of $\mathrm{Cd}$ in soil and plant part samples were found to be higher than the normal limits in all stations except Buyukada (as control), and the concentrations of Co in soil samples were found to be within the normal ranges, whereas the contents of $\mathrm{Ni}$ in uw and $\mathrm{w}$ leaf samples were detected as higher than the normal ranges in all stations except Buyukada (as control); however, the contents of $\mathrm{Ni}$ in bark samples were found to be within normal ranges. The concentrations of $\mathrm{Cr}$ and $\mathrm{Mn}$ in the plant and its co-located soil samples were found to be in normal ranges. Ni concentrations in soil samples were determined within the normal limits. Although $\mathrm{Ni}$ concentrations in the uw leaf samples were detected as higher than the normal ranges in all stations except Buyukada, Ni concentrations in the w leaf samples were found to be within the normal ranges. This shows that the higher Ni concentrations in uw leaf samples are due to the dust and debris containing $\mathrm{Ni}$ in the air adhering to the leaves. Finally, the concentrations of $\mathrm{Pb}$ in soil and plant part samples were determined as higher than the normal limits in all stations except Buyukada, not reaching the toxic level.

The relationships between heavy metal levels in the soil and $\mathrm{w}$ leaves of the plant in all localities

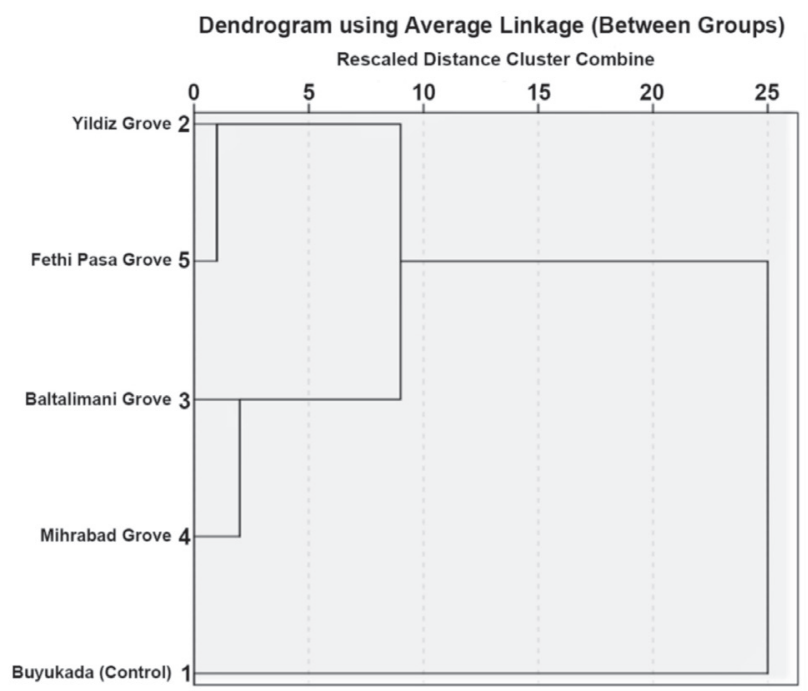

Fig. 4. Dendrogram constructed from 5 different locations based on the element compositions of sampled soils; generated with a hierarchical cluster analysis with average linkage (between localities).

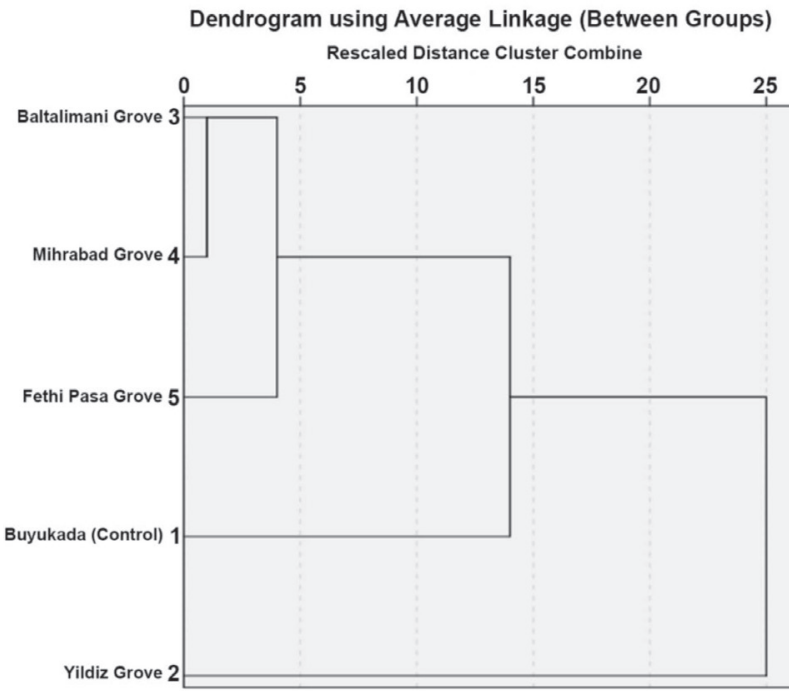

Fig. 5. Dendrogram constructed from 5 different locations based on the element compositions of sampled leaves; generated with a hierarchical cluster analysis with average linkage (between localities).

were shown in Figs 4 and 5 with hierarchical cluster analysis. When the comparisons were done between the dendrograms of leaf and soil, some differences were noticed between them. Baltalimani and Mihrabad Groves as a group were relatively close to the control, Yildiz and Fethi Pasha Groves as a group saw high concentrations detected and Buyukada (as control) as a group formed 3 groups all together (Fig. 4). This was also compatible with our graphics. However, when considering the situation on the leaf data, Baltalimani and Mihrabad Groves comprised a group and no such grouping was detected for the other localities (Fig. 5). This situation shows that the groups show similarity in terms of heavy metal contents within the soil samples, and that the choice of sites represent 3 different levels of pollution. Also, as a dynamic entity of the plant, it shows that the synergistic and antagonistic relationships between the elements in conjunction with physiological and biochemical processes of plants affect the heavy uptake and accumulation in the plant.

In addition, the washing procedure also significantly reduced the airborne deposition of heavy metals on plant leaves, and estimated highest to lowest accumulation rates (in \%), respectively, were between 23.78 (in station 4) and 18.44 (in control) for $\mathrm{Cd}, 28.21$ (in control) and 11.63 (in station 2) for $\mathrm{Co}, 21.83$ (in station 1) and 18.42 (in control) for $\mathrm{Cr}$ and 24.68 (in control) and 9.55 (in station 2) for $\mathrm{Pb}$ (Table 1).

Moreover, the highest outdoor $\mathrm{PM}_{10}$ value (in $\mu \mathrm{g} / \mathrm{m}^{3}$ ) was estimated as 67.792 at station, whereas the lowest outdoor $\mathrm{PM}_{10}$ value (in $\mu \mathrm{g} / \mathrm{m}^{3}$ ) was estimated as 37.483 at the control station. On the other hand, the highest outdoor $\mathrm{PM}_{2.5}$ (in $\mu \mathrm{g} / \mathrm{m}^{3}$ ) was recorded as 27.103 at station 1, whereas and the lowest outdoor $\mathrm{PM}_{2.5}$ (in $\mu \mathrm{g} / \mathrm{m}^{3}$ ) was found to be 11.216 at the 
Table 1 . Percentage change ( $\%$ removal) of heavy metal contents in leaves before and after washing.

\begin{tabular}{|c|c|c|c|c|c|}
\hline Heavy Metal & Buyukada (Control) & Yildiz Grove & Fethi Pasa Grove & Baltalimani Grove & Mihrabad Grove \\
\hline $\mathrm{Cd}$ & 18.44 & 22.19 & 22.08 & 20.55 & 23.78 \\
\hline $\mathrm{Co}$ & 28.21 & 12.08 & 11.63 & 12.45 & 13.51 \\
\hline $\mathrm{Cr}$ & 18.42 & 21.83 & 18.15 & 19.82 & 19.43 \\
\hline $\mathrm{Mn}$ & 22.50 & 23.81 & 16.72 & 14.13 & 11.78 \\
\hline $\mathrm{Ni}$ & 8.97 & 73.48 & 75.39 & 79.46 & 78.46 \\
\hline $\mathrm{Pb}$ & 24.68 & 11.64 & 9.55 & 12.74 & 12.04 \\
\hline
\end{tabular}

Table 2. Outdoor $\mathrm{PM}_{10}$ and $\mathrm{PM}_{2.5}$ levels (in $\mu \mathrm{g} / \mathrm{m}^{3}$ ) at sampling stations.

\begin{tabular}{|c|c|c|c|c|c|}
\hline $\mathrm{PM}$ & Buyukada (Control) & Yildiz Grove & Fethi Pasa Grove & Baltalimani Grove & Mihrabad Grove \\
\hline $\mathrm{PM}_{10}\left(\mu \mathrm{g} / \mathrm{m}^{3}\right)$ & 37.483 & 67.792 & 57.778 & 50.419 & 44.630 \\
\hline $\mathrm{PM}_{2.5}\left(\mu \mathrm{g} / \mathrm{m}^{3}\right)$ & 11.216 & 27.103 & 21.194 & 18.801 & 15.237 \\
\hline
\end{tabular}

control station (Table 2). We noticed that the highest metal concentrations were persistently recorded in station 1, which was relatively close to the highly crowded areas. The U.S. EPA's national air quality standards suggest that the measured annual mean (in $\mu \mathrm{g} / \mathrm{m}^{3}$ ) and daily concentration (in $\mu \mathrm{g} / \mathrm{m}^{3}$ ) have to be under 50 and $150 \mu \mathrm{g} / \mathrm{m}^{3}$ for $\mathrm{PM}_{10}$, and 15 and $35 \mu \mathrm{g} /$ $\mathrm{m}^{3}$ for $\mathrm{PM}_{2.5}$, respectively [39]. Therefore, particulate matter estimations for $\mathrm{PM}_{10}$ on an annual basis were not within the acceptable limits of the EPA at Yildiz, Fethi Pasha and Baltalimani Groves, and particulate matter estimations for $\mathrm{PM}_{2.5}$ on an annual basis were found to be at higher than normal limits except Buyukada. However, estimations on a daily basis were within the normal ranges at all stations for $\mathrm{PM}_{10}$ and $\mathrm{PM}_{2.5}$.

In this work, the results obtained from heavy metal concentration measurements in leaf (uw and w) and bark samples of Turkish red pine and its co-located soil samples were used for statistical analysis by employing multivariate analysis of variance (MANOVA) with Tukey's post-hoc HSD and Pearson correlation, and hierarchical cluster analysis were performed by using IBM SPSS Statistics 20 software. In the tests performed for 6 heavy metals, only the significant differences shown in Table 3 were found for $\mathrm{Cd}$, Ni and $\mathrm{Pb}$. When examined, the localities as 5 regions for $\mathrm{Cd}$ in the table were divided into 4 different subset ( $a, b, c$ and d), and Fethi Pasha Grove and Baltalimani Grove were found to be in the same subset. For Ni, 2 subsets ( $a$ and $b$ ) were taking place: Yildiz, Fethi Pasha and Baltalimani Groves were in one while Mihrabad Grove was shown similarity with Buyukada and 3 other localities found in the first subset. And for $\mathrm{Pb}$ in two subsets ( $\mathrm{a}$ and $\mathrm{b}$ ), the biggest difference was found for Yildiz Grove and Fethi Pasha, while Baltalimani and Mihrabad Groves were found to be shown similarly to Yildiz Grove and Buyukada (as control). All these results were considered with heavy metal concentrations determined; Yildiz
Grove, showing the highest level of heavy metal pollution, was generally found to be dominant to other groups. Buyukada, with the lowest level of heavy metal pollution, showed the actual control group characteristics. In other localities, the heavy metal pollution rates were found to be in close proximity to each other. This situation could be explained by traffic density and the direction of the wind.

In addition, the results from Pearson correlation test performed by using the data obtained from the measurements of heavy metal concentrations in all plant parts and soil samples were given in Table 4. When examined, it was understood that there was no negative correlation between the 6 heavy metals. On the contrary, 6 heavy metals had high positive correlations with each other $(>0.59,>0.99)$.

In previous studies done with Pinaceae family members, Dogan et al. [28] used Turkish red pine barks for estimating heavy metal pollution along control, rural, suburban and roadside areas in Western Anatolia, and the values (in $\mathrm{mg} \mathrm{kg}^{-1}$ ) were found as $0.68,0.63$, 0.68, 0.60 for $\mathrm{Cd}$; $0.44,0.84,0.89,1.24$ for $\mathrm{Cr}$; 3.56,

Table 3. Multivariate analysis of variance (MANOVA) with Tukey's post-hoc HSD were performed and means for group in homogeneous subsets were displayed; the levels of statistical significance were expressed as $0.01\left(^{* *}\right)$ and $0.05\left(^{*}\right)$; Tukey's post-hoc test were for localities.

\begin{tabular}{|c|c|c|c|}
\hline Localities & $\mathrm{Cd}$ & $\mathrm{Ni}$ & $\mathrm{Pb}$ \\
\hline Buyukada (Control) & $0.496^{\mathrm{d}}$ & $2.790^{\mathrm{b}}$ & $11.701^{\mathrm{b}}$ \\
\hline Yildiz Grove & $1.434^{* *_{\mathrm{a}}}$ & $7.954^{* *_{\mathrm{a}}}$ & $27.436^{*_{\mathrm{a}}}$ \\
\hline Fethi Pasa Grove & $1.240^{* * \mathrm{~b}}$ & $7.000^{* * \mathrm{a}}$ & $24.713^{\mathrm{ab}}$ \\
\hline Baltalimani Grove & $1.186^{* *_{\mathrm{b}}}$ & $6.393^{* *_{\mathrm{a}}}$ & $22.956^{\mathrm{ab}}$ \\
\hline Mihrabad Grove & $0.898^{* *_{\mathrm{c}}}$ & $5.518^{\mathrm{ab}}$ & $21.063^{\mathrm{ab}}$ \\
\hline
\end{tabular}


Table 4. Correlation coefficients between heavy metals determined in plant and soil samples.

\begin{tabular}{|c|c|c|c|c|c|}
\hline \multicolumn{7}{|c|}{ Correlation Matrix (R) } \\
\hline Pearson Correlation & $\mathrm{Co}$ & $\mathrm{Cr}$ & $\mathrm{Mn}$ & $\mathrm{Ni}$ & $\mathrm{Pb}$ \\
\hline $\mathrm{Cd}$ & $.591^{* *}$ & $.620^{* *}$ & $.590^{* *}$ & $.818^{* *}$ & $.683^{* *}$ \\
\hline $\mathrm{Co}$ & & $.989^{* *}$ & $.995^{* *}$ & $.878^{* *}$ & $.982^{* *}$ \\
\hline $\mathrm{Cr}$ & & & $.983^{* *}$ & $.895^{* *}$ & $.981^{* *}$ \\
\hline $\mathrm{Mn}$ & & & & $.877^{* *}$ & $.987^{* *}$ \\
\hline $\mathrm{Ni}$ & & & & $.913^{* *}$ \\
\hline
\end{tabular}

${ }^{* *}$ Correlation is significant at the 0.01 level (2-tailed)

5.11, 4.26, 3.72 for $\mathrm{Ni}$; and finally 4.59, 7.32, 9.02, 16.15 for $\mathrm{Pb}$. Sawidis et al. [40] used leaves and barks of Pinus sp. in their study in Salzburg, Belgrade and Thessaloniki and the values (in $\mathrm{mg} \mathrm{kg}^{-1}$ ) in the leaves and barks of Pinus sp. found for control in 3 cities (Salzburg, Belgrade and Thessaloniki) were 0.39 (in leaves)/0.31 (in barks), 0.33 (in leaves)/0.59 (in barks), 0.31 (in leaves) $/ 0.88$ (in barks) for $\mathrm{Cr}$ and 2.44 (in leaves)/1.09 (in barks), 2.22 (in leaves)/2.05 (in barks), 2.81 (in leaves) $/ 2.05$ (in barks) for $\mathrm{Pb}$, while the values (in $\mathrm{mg} \mathrm{kg}^{-1}$ ) in the leaves and barks of Pinus sp. found for polluted areas in 3 cities (Salzburg, Belgrade and Thessaloniki) were 0.42 (in leaves) $/ 0.41$ (in barks), 0.58 (in leaves) $/ 0.83$ (in barks), 0.66 (in leaves) $/ 0.14$ (in barks) for $\mathrm{Cr}$ and 2.46 (in leaves) $/ 5.98$ (in barks), 14.45 (in leaves)/15.57 (in barks), 12.74 (in leaves)/9.15 (in barks) for $\mathrm{Pb}$. Miri et al. [41] used the leaves of Pinus eldarica as study material in their research done in Yazd City in Iran, where the concentrations of $\mathrm{Cd}$ and $\mathrm{Pb}$ in $\mathrm{mg} \mathrm{kg} \mathrm{kg}^{-1}$ were found to be 0.74 and 2.99, respectively. Research done by Coskun [42] in the Thrace region in Turkey using the barkss of Pinus nigra found the concentrations of $\mathrm{Cd}$ and $\mathrm{Pb}$ (in $\mathrm{mg} \mathrm{kg}$ $\left.{ }^{1}\right)$ as 0.16 and 12.9, respectively; and the concentrations of $\mathrm{Cd}, \mathrm{Mn}, \mathrm{Ni}$ and $\mathrm{Pb}$ (in $\mathrm{mg} \mathrm{kg}^{-1}$ ) were $0.37,29.2$, 0.54 and 2.1 in a study done by Harju et al. [43] in Merimasku City in Finland using the barks of Pinus sylvestris. A comparison of all the data from previous studies performed with Pinus sp. mentioned above and the data obtained from our study showed that although there were no big differences, occasional fluctuations were noted, generally higher than previous studies.

In our study, the highest heavy metal concentrations were detected in Yildiz Grove in Besiktas District, whereas the lowest heavy metal concentrations were detected in Buyukada (as control). A previous study done in the same research areas using Celtis australis L. and its co-located soil samples as study materials produced similar results showing the lowest values in Buyukada (as control), whereas the highest values were in Besiktas for $\mathrm{Cd}$ and $\mathrm{Pb}$, respectively [15]. A particulate matter metal component study was performed in 4 districts of Istanbul by Sahin et al. [44], and its findings showed that the higher heavy metal concentrations were detected in Besiktas, which has heavier traffic congestion than the other districts.

\section{Conclusions}

Based on EPA projections, $\mathrm{PM}_{10}$ could likely cause adverse health effects because of its particulate capability for reaching the respiratory tract [39]. In this work, PM values were estimated as normal based on the daily amounts. On the other hand, these values at some stations were found to be higher than the EPA's standards based on annual amounts (Table 2). So, when considered together with high heavy metal concentrations, it can be said that people living in Istanbul could suffer from airborne diseases in the future if necessary precautions are not implemented.

The data from our study showed that high concentrations of heavy metals were detected in Yildiz Grove in the soil samples and also in plant part samples, whereas low concentrations for heavy metals were detected in Buyukada in soil samples and also in plant part samples. Compatible results were obtained in other regions. Therefore, overall accumulation levels of different heavy metals $(\mathrm{Cd}, \mathrm{Co}, \mathrm{Cr}$ and $\mathrm{Pb})$ in plant parts suggests that Turkish red pine as a biomonitor organism provided useful information for evaluating pollution levels in Istanbul.

\section{Conflict of Interest}

The authors declare no conflict of interest.

\section{References}

1. PRAJAPATI S.K., MERAVI N., SINGH S. Phytoremediation of chromium and cobalt using Pistia stratiotes: a sustainable approach. Proceedings of the International Academy of Ecology and Environmental Sciences, 2 (2), 136, 2012.

2. SALIH Z., AZIZ F. Heavy metals accumulation in leaves of five plant species as a bioindicator of steel factory 
pollution and their effects on pigment content. Pol J Environ Stud, 28 (6), 4351, 2019.

3. WU W., WU P., YANG F., SUN D.L., ZHANG D.X., ZHOU Y.K. Assessment of heavy metal pollution and human health risks in urban soils around an electronics manufacturing facility. Sci Total Environ, 630, 53, 2018.

4. PATRA P., MOHANDASS C., CHAKRABORTY P. Snapshot of environmental condition in different tropical estuarine systems by using $S$. cucullata (an edible oyster) as bio-indicator. Environ Sci Pollut Res, 26 (11), 11342, 2019.

5. ARICAK B., CETIN M., ERDEM R., SEVIK H., COMETEN H. The usability of scotch pine (Pinus sylvestris) as a biomonitor for traffic-originated heavy metal concentrations in Turkey. Pol J Environ Stud, 29 (2), 1051, 2020.

6. VURAL A., GUNDOGDU A., AKPINAR I., BALTACI C. Environmental impact of Gümüşhane City, Turkey, waste area in terms of heavy metal pollution. Nat Hazards, $\mathbf{8 8}(2), 867,2017$

7. NAILA A., MEERDINK G., JAYASENA V., SULAIMAN A.Z., AJIT A.B., BERTA, G. A review on global metal accumulators-mechanism, enhancement, commercial application, and research trend. Environ Sci Pollut Res, 1, 2019.

8. SEVEROGLU Z., OZYIGIT I.I., DOGAN I., KURMANBEKOVA G., DEMIR G., YALCIN I.E., KARI G.K. The usability of Juniperus virginiana L. as a biomonitor of heavy metal pollution in Bishkek City, Kyrgyzstan. Biotechnol Biotec Eq, 29 (6), 1104, 2015.

9. SCIMECA M., BISCHETTI S., LAMSIRA H.K., BONFIGLIO R., BONANNO E. Energy Dispersive X-ray (EDX) microanalysis: A powerful tool in biomedical research and diagnosis. Eur J Histochem, 62 (1), 2018.

10. GUPTA S., HE W.D., TAI N.H. A comparative study on superhydrophobic sponges and their application as fluid channel for continuous separation of oils and organic solvents from water. Compos Part B-Eng, 101, 99, 2016.

11. OZYIGIT I.I., DOGAN I., IGDELIOGLU S., FILIZ E., KARADENIZ S., UZUNOVA Z. Screening of damage induced by lead $(\mathrm{Pb})$ in rye (Secale cereale $\mathrm{L}$.) a genetic and physiological approach. Biotechnol Biotec Eq, 30 (3), 489, 2016.

12. MALKOWSKI E., SITKO K., ZIELEZNIKRUSINOWSKA P., GIERON Ż., SZOPINSKI M. Heavy Metal Toxicity: Physiological Implications of Metal Toxicity in Plants. In Plant Metallomics and Functional Omics, 253-301, Springer, Cham., 2019.

13. AHMAD K., ASHFAQ A., KHAN Z.I., BASHIR H., SOHAIL M., MEHMOOD N., DOGAN Y. Metal accumulation in Raphanus sativus and Brassica rapa: an assessment of potential health risk for inhabitants in Punjab, Pakistan. Environ Sci Pollut R, 1, 2018.

14. WHO - National Burden of Disease Estimates - World Health Organization. 2007. http://www.who.int/indoorair/ publications/indoor_air_national_burden_estimate_ revised.pdf?ua $=1$

15. OZTURK A., YARCI C., OZYIGIT I.I. Assessment of heavy metal pollution in Istanbul using plant (Celtis australis L.) and soil assays. Biotechnol Biotech Eq, 31 (5), 948-954, 2017.

16. OZYIGIT I.I., UYANIK O.L., SAHIN N.R., YALCIN I.E., DEMIR G. Monitoring the pollution level in Istanbul coast of the Sea of Marmara using algal species Ulva lactuca L. Pol J Environ Stud, 26 (2), 773, 2017.
17. JOSEPHINE A.A., CHBANI A., FALJOUN Z., MILLET $M$. The use of vegetation, bees, and snails as important tools for the biomonitoring of atmospheric pollution - a review. Environ Sci Pollut Res, 26 (10), 9391, 2019.

18. DE LA CRUZ A.R.H., DE LA CRUZ J.K.H., TOLENTINO D.A., GIODA A. Trace element biomonitoring in the Peruvian andes metropolitan region using Flavoparmelia caperata lichen. Chemosphere, 210, 849, 2018.

19. DEMKOVÁ L., BOBUL'SKÁ L., ÁRVAY J., JEZNÝ T., DUCSAY L. Biomonitoring of heavy metals contamination by mosses and lichens around Slovinky tailing pond (Slovakia). J Environ Sci Health, Part A, 52 (1), 30, 2017.

20. CAGLAYAN C., TASLIMI P., TURK C., KANDEMIR F.M., DEMIR Y., GULCIN I. Purification and characterization of the carbonic anhydrase enzyme from horse mackerel (Trachurus trachurus) muscle and the impact of some metal ions and pesticides on enzyme activity. Comparat Biochem Physiol Part C, 108605, 1, 2019.

21. OSYCZKA P., ROLA K. Integrity of lichen cell membranes as an indicator of heavy metal pollution levels in soil. Ecotoxicol Environ Safety, 174, 26, 2019.

22. BONANNO G., BORG J.A., DI MARTINO V. Levels of heavy metals in wetland and marine vascular plants and their biomonitoring potential: a comparative assessment. Sci Total Environ, 576, 796, 2017.

23. CHOWANIAK M., NIEMIEC M., PALUCH L. Bioconcentration of cadmium $(\mathrm{Cd})$, copper $(\mathrm{Cu})$, lead $(\mathrm{Pb})$ and zinc $(\mathrm{Zn})$ in Lactarius salmonicolor in the Western Carphatians. J Elementol, 22 (4), 1537, 2017.

24. COSMA C., IURIAN A.R., INCZE R., KOVACS T., ŽUNIĆ Z.S. The use of tree bark as long term biomonitor of 137Cs deposition. J Environ Radioactiv, 153, 126, 2016.

25. SETA-KOSELSKA A., SZCZUKA E., SKÓRZYŃSKAPOLIT E., DOMACIUK M., GIEŁWANOWSKA I. Roadside larch trees (Larix Mill.) and its female generative organs as a biomonitor of air pollution. Pol J Environ Stud, 23 (3), 2014.

26. BICAKCI A., TOSUNOGLU A. Allergenic pollen in Turkey. Asthma Allergy Immunol, 1, 2019.

27. URQUHART J., MARZANO M., POTTER C. The human dimensions of forest and tree health: Global perspectives. Springer, 1, 2018.

28. DOGAN Y., UGULU I., BASLAR S. Turkish Red Pine as a biomonitor: a comparative study of the accumulation of trace elements in the needles and bark. Ekoloji, 19 (75), 88, 2010.

29. OZDEMIR H., MERTOGLU B., DEMIR G., DENIZ A., TOROS H. Case study of PM pollution in playgrounds in Istanbul. Theor Appl Climatol, 108 (3-4), 553, 2012.

30. TUIK (Turkish Statistical Institute) 2019. http://rapor.tuik. gov.tr/reports/rwservlet?adnksdb2\&ENVID=adnksdb2Env \&report=wa turkiye_ilce_koy_sehir.RDF\&p_il1=34\&p kod=1\&p_yil $=2012 \& p \_d i l=1 \&$ desformat.

31. IBB (Istanbul Metropolitan Munucipality) 2019. http:// www.ibb.gov.tr/sites/ks/en-us/Pages/Home.aspx.

32. TEKELI E., BASKAYA F.T. Revealing strategies for the green heritage of Istanbul he case of historical groves. WIT Transactions on Ecology and the Environment, 193, 597, 2015.

33. MONTADKA N.P. Comprehensive Analysis of $\mathrm{PM}_{2.5}$ Pollution from Construction Activities, Oregon State University, 2017. 
34. KABATA-PENDIAS A., MUKHERJEE A.B. Trace elements from soil to human. Springer, Berlin Heidelberg, New York, 1, 2007.

35. KABATA-PENDIAS A., PENDIAS H. Trace elements in soils and plants. $3^{\text {rd }}$ ed., CRC Press, Boca Raton New York, Washington, D.C. 1, 2001.

36. BLUM W.E.H., HORAK O., MENTLER A., PUSCHENREITTER M. Trace elements. environmental and ecological chemistry, Sabljic A. Encyclopedia of Life Support Systems (EOLSS), Developed under the Auspices of the UNESCO, Oxford, UK. 2004.

37. PAWLISZ A.V., KENT R.A., SCHNEIDER U.A., JEFFERSON C. Canadian water quality guidelines for chromium. Environ Toxicol, 12 (2), 123, 1997.

38. SERBULA S.M., MILJKOVIC D.D., KOVACEVIC, R.M., ILIC, A.A. Assessment of airborne heavy metal pollution using plant parts and topsoil. Ecotox Environ Safe, 76, 209-214, 2012.

39. EPA - United States Environmental Protection Agency. 2011. http://www.epa.gov.
40. SAWIDIS T., BREUSTE J., MITROVIC M., PAVLOVIC P., TSIGARIDAS K. Trees as bioindicator of heavy metal pollution in three European cities. Environ Pollut, 159 (12), 3560, 2011.

41. MIRI M., EHRAMPOUSH M.H., GHAFFARI H.R., AVAL H.E., REZAI M., NAJAFPOUR F., EBRAHIMI A. Atmospheric heavy metals biomonitoring using a local Pinus eldarica tree. Health Scope, 6 (1), 2017.

42. COSKUN M. Toxic metals in the Austrian pine (Pinus nigra) bark in the Thrace region, Turkey. Environ Monit Assess, 121 (1-3), 173, 2006.

43. HARJU L., SAARELA K.E., RAJANDER J., LILL J.O., LINDROOS A., HESELIUS S.J. Environmental monitoring of trace elements in bark of Scots pine by thicktarget PIXE. Nuclear Instruments and Methods in Physics Research Section B: Beam Interactions with Materials and Atoms, 189 (1-4), 163, 2002.

44. SAHIN U.A., POLAT G., ONAT B. Mass size distribution and source identification of particulate matter metal components at four urban sites and a background site of Istanbul. Environ Sci Pollut R, 23 (11), 11085, 2016. 